Article

\title{
Administration of Asian Herb Bennet (Geum japonicum) Extract Reverses Depressive-Like Behaviors in Mouse Model of Depression Induced by Corticosterone
}

\author{
Dong Wook Lim ${ }^{1}$, Taewon Han ${ }^{2}$, min Young Um ${ }^{1,3}$, minseok Yoon ${ }^{1}$, Tae-Eun Kim ${ }^{1}$, \\ Yun Tai Kim ${ }^{1,3} \mathbb{D}$, Daeseok Han ${ }^{1}$, Jaekwang Lee ${ }^{1}$ and Chang Ho Lee ${ }^{1, *}$ \\ 1 Research Division of Functional Food Functionality, Korea Food Research Institute, Wanju 55365, Korea; \\ dwlim@kfri.re.kr (D.W.L.); myum@kfri.re.kr (M.Y.U.); msyoon@kfri.re.kr (M.Y.); tekim@kfri.re.kr (T.-E.K.); \\ ytkim@kfri.re.kr (Y.T.K.); imissu@kfri.re.kr (D.H.); jklee@kfri.re.kr (J.L.) \\ 2 Food Functional Evaluation Support Team, Korea Food Research Institute, Wanju 55365, Korea; \\ korea498@kfri.re.kr \\ 3 Division of Food Biotechnology, University of Science \& Technology, Daejeon 34113, Korea \\ * Correspondence: chang@kfri.re.kr; Tel.: +82-63-219-9226
}

Received: 4 October 2019; Accepted: 18 November 2019; Published: 20 November 2019

check for updates

\begin{abstract}
Geum japonicum, commonly known as Asian herb bennet, has been used as a diuretic, astringent, anti-dizziness, and anti-headache agent in traditional medicine. Since the antidepressantlike effects of $G$. japonicum extract have not been well studied, we examined the antidepressant-like effects of G. japonicum extract using depressive-like behavior induced in mice through daily injection of corticosterone (CORT). ICR mice (male, 8 weeks old) were treated with CORT ( $40 \mathrm{mg} / \mathrm{kg}$, i.p.) and orally administered using oral gavage needles with G. japonicum extract (30, 100, and $300 \mathrm{mg} / \mathrm{kg}$ ) for 4 weeks. Behavioral experiments were performed $1 \mathrm{~h}$ after administration. The control mice exhibited a significant increase in the immobility times in the tail suspension and forced swim tests as well as the step-through latency time in the passive avoidance test. Further, the control group showed a significant decrease in their sucrose consumption. However, treatment with G. japonicum extract at doses of 100 and $300 \mathrm{mg} / \mathrm{kg}$ significantly improved these depression-like behaviors without altering the locomotor activity. Moreover, treatment with G. japonicum extract significantly prevented the decrease in the expression of brain-derived neurotrophic factor (BDNF) in the hippocampus. In addition, G. japonicum extract had neuroprotective effects against CORT-induced neurotoxicity in SH-SY5Y cells. Our study indicates that G. japonicum extract exhibits antidepressant-like activity in CORT-induced depressive mice, which might be as a result of increased BDNF expression.
\end{abstract}

Keywords: Geum japonicum; antidepressant; neuroprotective; corticosterone; hypothalamic-pituitaryadrenal axis

\section{Introduction}

Depression is one of the most significant global health problems with an estimated more than 300 million patients worldwide [1]. However, currently available first-line antidepressants are not completely effective and usually cause a large number of undesirable side effects [2]. Thus, alternative approaches, including folk medicinal herbs, such as Hypericum perforatum, commonly known as St. John's Wort [3], or increased consumption of antioxidants from fruits and vegetables $[4,5]$ have garnered interest as potential antidepressant agents.

Geum japonicum, commonly known as Asian herb bennet, is used as a diuretic, astringent, anti-dizziness, and anti-headache agent in traditional Chinese medicine [6]. Previous studies have 
reported that G. japonicum crude extract and its active compounds such as triterpenoids have anticoagulant [7], antioxidant [8], anti-HIV [9], angiogenic [10], and vasorelaxant [11] activities. Ou et al. recently reported that G. japonicum extract has neuroprotective effects in the middle cerebral artery occlusion model via inhibition of inflammatory-mediated factors [12]. Nigaichigoside F1, isolated from G. japonicum, has been reported to alleviate hepatic steatosis in high-fat-diet-induced obese mice by regulating lipid metabolism genes [13]. The active fraction isolated from G. japonicum has also been reported to enhance capillary tube formation and promote the growth of new coronary collaterals in the ischemic region of the heart in the chronic coronary heart disease rat model [14]. However, the antidepressant-like effects of G. japonicum extract have not been well examined.

In this study, we aimed to investigate the antidepressant-like effects of G. japonicum extract in a depression animal model established by repeated chronic administration of corticosterone (CORT) injection. The CORT-induced depression model has been reported to be valid for evaluating the efficacy of potential antidepressants [15]. Further, we evaluated the neuroprotective effects of G. japonicum extract on CORT-induced neurotoxicity in human neuroblastoma SH-SY5Y cells.

\section{Materials and Methods}

\subsection{Preparation of the Standardized Geum japonicum}

Dried G. japonicum $(300 \mathrm{~g})$ was extracted with $70 \%$ ethanol $(3000 \mathrm{~mL})$ at $80^{\circ} \mathrm{C}$ for $6 \mathrm{~h}$. The extract was filtered and lyophilized to dry powder. The yield of G. japonicum extract was $9.1 \%$. The analysis of 3, 4, 5-trihydroxybenzaldehyde (3, 4, 5-THBA)(Sigma-Aldrich, MO, USA), an active or a standard compound [16] in G. japonicum extract, was performed on a high-performance liquid chromatography system (Jasco, Hachioji, Tokyo, Japan) equipped with a PU-980 pump, AS-950-10 autosampler, and MD-2010 PDA detector. An analytical chromatogram was obtained at $30{ }^{\circ} \mathrm{C}$ on a Waters Sunfire ${ }^{\mathrm{TM}}$ C18 $5 \mu \mathrm{m}$ column $(4.6 \mathrm{~mm} \times 250 \mathrm{~mm})$ through gradient elution using a mobile phase composed of water, $0.2 \%(v / v)$ formic acid, and acetonitrile/MeOH $(60: 40, v / v)$. We performed gradient separation using $0.2 \%$ formic acid. The gradient was decreased by $90 \%$ from 0 to $10 \mathrm{~min}, 77 \%$ from 10 to $15 \mathrm{~min}$, $40 \%$ from 15 to $35 \mathrm{~min}$, and was increased by $90 \%$ from 35 to $40 \mathrm{~min}$. The run time and flow rate were set at $40 \mathrm{~min}$ and $1.0 \mathrm{~mL} / \mathrm{min}$, respectively, while the samples were detected at $330 \mathrm{~nm}$. The concentration of 3, 4, 5-THBA in extract powder was found to be $3.5 \pm 0.12 \mathrm{mg} / \mathrm{g}$ using the peak area in the standard chromatogram (Figure 1).

\subsection{Animals}

All animal experiments were approved by the Institutional Animal Care and Use Committee of the Korea Food Research Institute (KFRI-M-19016). ICR mice (male, 7 weeks old, weighing 30-32 g) were purchased from KOATECH Animal Inc. (Pyeongteak, South Korea). The mice were kept at five mice per cage with free access to food and water prior to the experiments under controlled temperature $\left(21 \pm 2{ }^{\circ} \mathrm{C}\right)$ with a $24 \mathrm{~h} \mathrm{(12} \mathrm{h:12} \mathrm{h)} \mathrm{light-dark} \mathrm{cycle,} \mathrm{(lights} \mathrm{on} \mathrm{at} \mathrm{07:00,} \mathrm{and} \mathrm{lights} \mathrm{off} \mathrm{at} \mathrm{19:00).} \mathrm{The} \mathrm{mice}$ were acclimated at least 1 week prior to the experiments.

\subsection{Corticosterone (CORT) and Extracts Administration}

CORT (Sigma-Aldrich, MO, USA) was dissolved in $0.9 \%(w / v)$ saline containing $1 \%$ Tween- 80 . G. japonicum extract or St. John's wort (Hypericum japonicum $80 \% \mathrm{MeOH}$ extract dried powder), which was the positive control, were dissolved in distilled water. The mice were randomly assigned to six groups of 10 mice each as follows: (1) the sham group; (2) control group; (3) St. John's wort $300 \mathrm{mg} / \mathrm{kg}$; (4) G. japonicum extract $30 \mathrm{mg} / \mathrm{kg}$; (5) G. japonicum extract $100 \mathrm{mg} / \mathrm{kg}$; and (6) G. japonicum extract $300 \mathrm{mg} / \mathrm{kgtreated}$ group. Mice in the control group and the samples-treated groups were orally administered using gavage needles with received CORT (40 mg/kg, i.p.) injections once daily for 4 weeks, while those in the sham group were orally administered with distilled water and received intraperitoneal (i.p.) injections of an equal volume of vehicle. After 3 weeks of treatments, the mice 
underwent the depression-related behavioral tests beginning 1 hour after sample administration, as following the experimental scheme, for a week (Figure 2A) and were then sacrificed for western blots analysis.
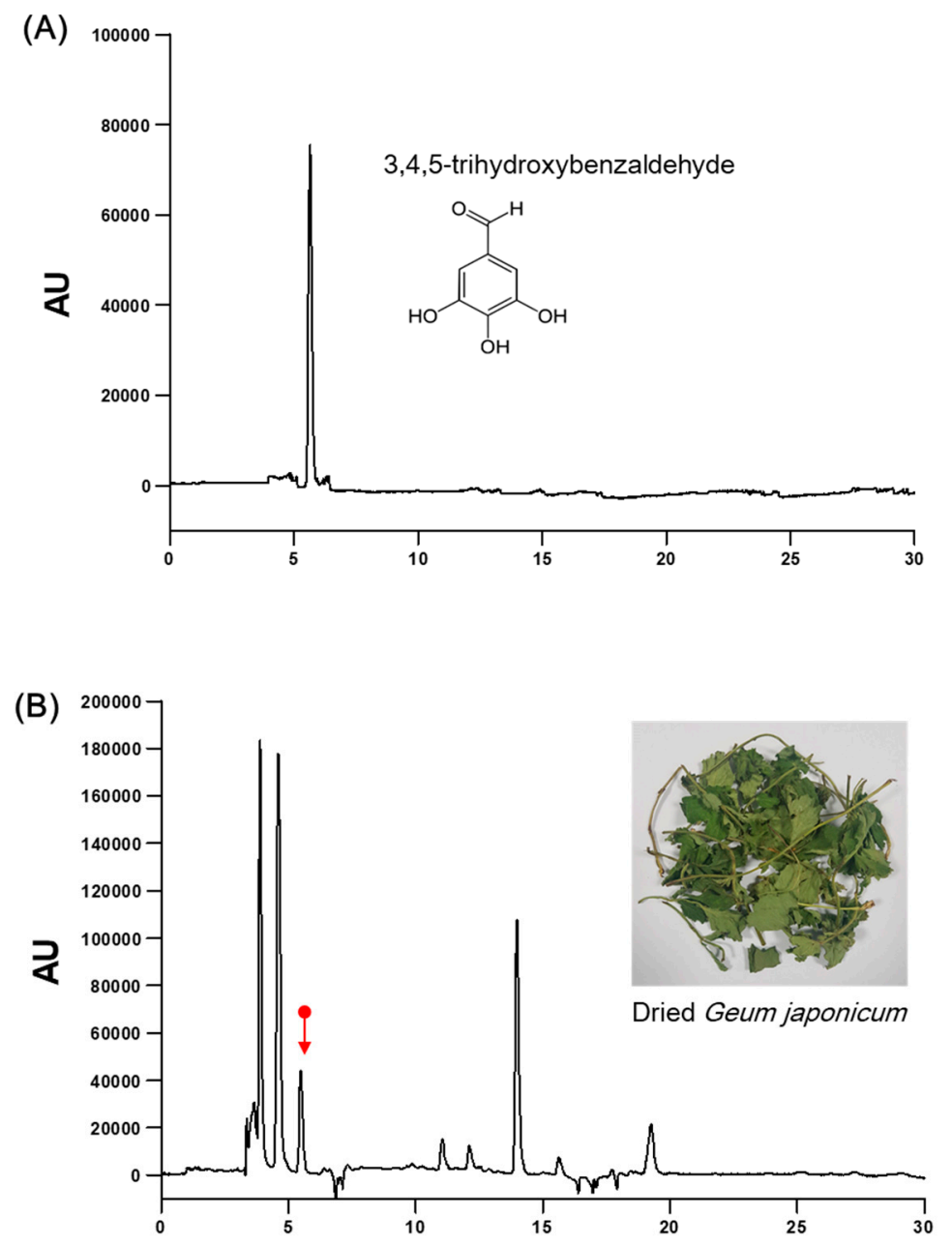

Figure 1. High-performance liquid chromatography (HPLC) chromatogram for standardization of G. japonicum extract. (A) HPLC chromatograms for 3, 4, 5-trihydroxybenzaldehyde and (B) G. japonicum extract. $\mathrm{X}$-axis, retention time (min); Y-axis, absorbance unit (AU).

\subsection{Open Field Test (OFT)}

After 3 weeks of treatment of G. japonicum extract or St. John's wort, the OFT was performed as previously described [16]. To study locomotor activity, the mice were located in open maze $(50 \times 50 \times$ $50 \mathrm{~cm}$ arena). Their locomotor-related behaviors recorded and measured the total distance and times in zone periphery and center for 5 min using SMART v3.0 software (Panlab SL, Barcelona, Spain).

\subsection{Sucrose Preference Test (SPT)}

The SPT was performed 24 hours after OFT, following a previously established protocol [17]. The two bottles contained the $1 \%$ sucrose solutions were located in the cage for $24 \mathrm{~h}$. Next, one of the bottle of the sucrose solution was located with water for $24 \mathrm{~h}$. The mice then were placed in cages individually with free access to the two bottles for $24 \mathrm{~h}$, and the consumed volumes were recorded. Sucrose preference was calculated as follows: consumption $(\%)=[$ sucrose intake/(sucrose intake + water intake)] $\times 100$. 


\subsection{Passive Avoidance Test (PAT)}

The PAT was performed 24 hours after SPT, as in a previously described protocol for depression-related learning and memory [18]. The mice were tested in the passive-avoidance task (GEMINI, SD instruments, San Diego, CA, USA). In the training trial, each mouse was placed in the safe compartment with the closed door. After 1 min of acclimatization, the door opened and the mice were allowed to enter the dark compartment. When the mice entered the dark compartment, the mice received an inescapable electrical foot shock of $0.5 \mathrm{~mA}$ for $3 \mathrm{~s}$. On the next day, the mice were again placed in the safe compartment, and the latency to enter the dark compartment was recorded.

(A)

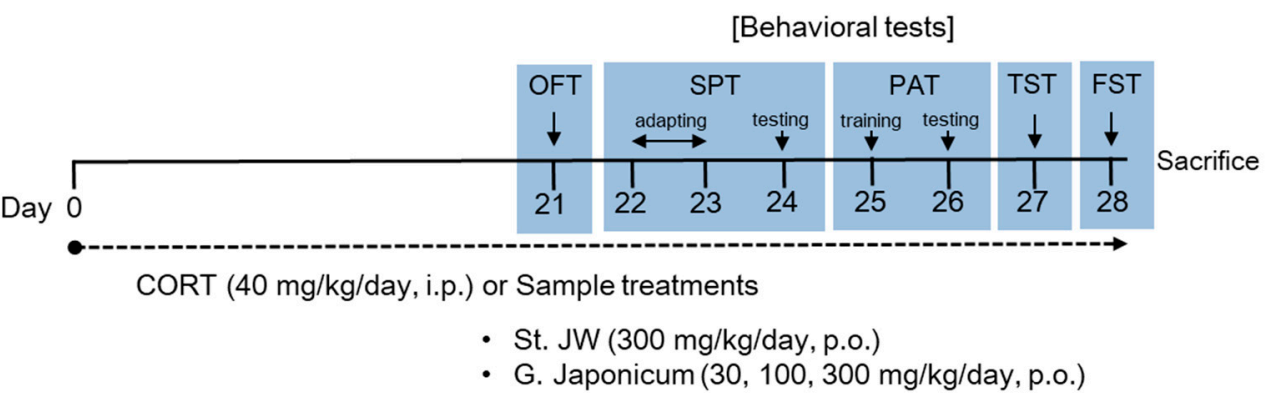

(B)

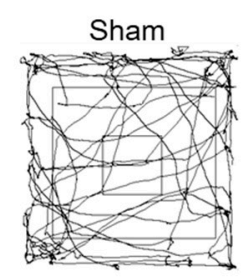

St. JW

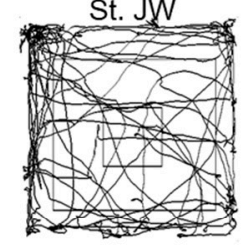

(D)

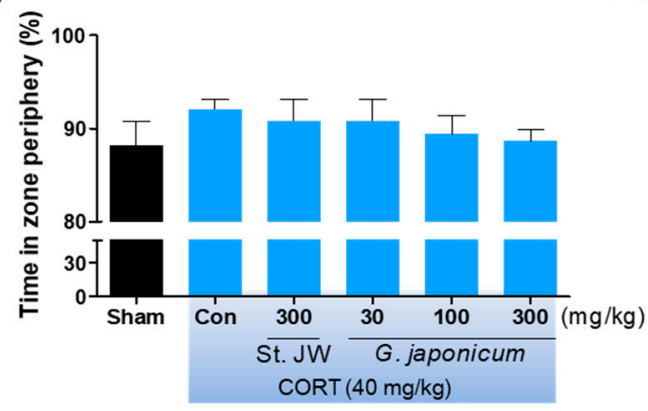

(C)

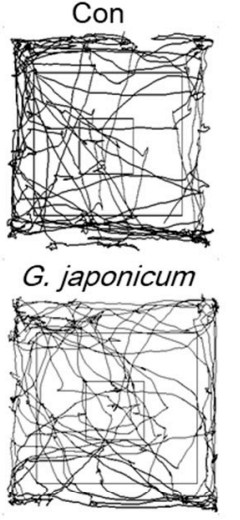

(E)
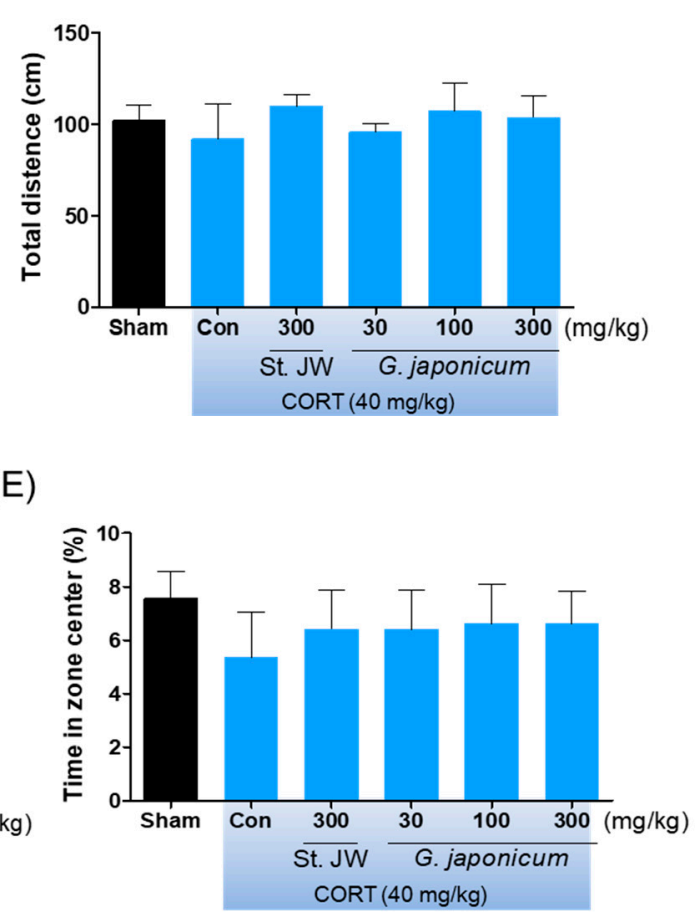

Figure 2. The effect of G. japonicum extract on the open field test in corticosterone (CORT)-induced depressive mice. (A) Study design of the experiments to evaluate the effect of G. japonicum extract. (B) Individual examples of locomotor activity are shown. (C) Total distance $(\mathrm{cm})$ in traveled in OFT. (D) The number of line crossing in the periphery of the field. (E) The number of line crossing in the center of the field. There was no significant among-group difference in the locomotor activity. Results are presented as mean \pm SEM. 


\subsection{Tail Suspension Test (TST)}

To verify whether G. japonicum extract has antidepressant-like effects, the TST immobility was performed 24 hours after PAT. The mice were suspended by the tail using an adhesive tape attached to a hook connected to a strain gauge. The automated device (BioSeb, Chaville, France) was used to score immobility during the last $6 \mathrm{~min}$.

\subsection{Forced Swim Test (FST)}

The FST immobility was performed 24 hours after TST. The mice were forced to swim by being individually placed in a clear Plexiglas cylinder $(13 \mathrm{~cm}$ in height and $24 \mathrm{~cm}$ in diameter) filled with water $\left(22-24^{\circ} \mathrm{C}, 10 \mathrm{~cm}\right.$ depth) for $6 \mathrm{~min}$. The immobility time was determined during the last $4 \mathrm{~min}$ by SMART v3.0 software (Panlab SL, Barcelona, Spain).

\subsection{Western Blotting}

Mice were sacrificed by decapitation immediately after FST, the hippocampus was quickly isolated from brain. The hippocampus was homogenized in RIPA buffer containing protease inhibitor (Thermo Scientific, Waltham, MA, USA). The quantified proteins were separated by electrophoresis on $10 \%$ SDS-polyacrylamide gel electrophoresis (PAGE) and transferred onto polyvinylidene fluoride (PVDF) membranes (Millipore, Billerica, MA, USA). The membranes were blocked for $1 \mathrm{~h}$ at room temperature using $4 \%$ skimmed milk in Tris-buffer saline and probed overnight at $4{ }^{\circ} \mathrm{C}$ with primary antibodies raised against pro-BDNF (brain-derived neurotrophic factor) (1:1000 dilution, sc-65514, Santa Cruz Biotechnology, CA, USA). The membranes were incubated with the horseradish peroxidase-linked secondary antibody for $2 \mathrm{~h}$. Then, immunoreactive proteins were detected by imaging systems; chemiluminescence (LI-COR Biosciences, Lincoln, NE, USA) and determined using the ImageJ software (NIH, Bethesda, MD, USA).

\subsection{Cell Viability Assay}

SH-SY5Y cells were cultured in Dulbecco's Modified Eagle Medium (DMEM) (Gibco, NY, USA) containing $10 \%$ fetal bovine serum and $1 \%$ penicillin-streptomycin-glutamine. The cells were incubated in a humidified environment with $5 \% \mathrm{CO}_{2}$ at $37^{\circ} \mathrm{C}$. The cell viability was determined by using the 3-(4, 5-dimethylthiazol-2-yl)-2, 5-diphenyltetrazolium bromide (MTT) assay. Briefly, the cells were seeded in 96-well plates $\left(2 \times 10^{4}\right.$ cells/well) and co-treated with 30,50, or $100 \mu \mathrm{g} / \mathrm{mL}$ of G. japonicum extract and CORT $(200 \mu \mathrm{m})$ for $24 \mathrm{~h}$. Next, MTT reagent $(5 \mathrm{mg} / \mathrm{mL})$ was added to the cell. After the plate incubation for $4 \mathrm{~h}$, the medium was lysed and the formazan product was dissolved by DMSO. Cell viability was quantified by measuring the optical density at $570 \mathrm{~nm}$ using a microplate reader.

\subsection{Statistical Analysis}

Multiple between-group differences were compared using one-way analysis of variance followed by the Tukey's post hoc test using Prism 5 (GraphPad Software, Inc., San Diego, CA, USA). All data were presented as mean \pm standard error of the mean (SEM). Differences with $p<0.05$ were considered significant.

\section{Results}

\subsection{Effect of G. japonicum Extract on OFT}

There was no significant among-group difference in the time spent in the center/periphery area and the total distance covered on the OFT (Figure 2B-E). Further, CORT injection did not have a significant effect on body weight (data not shown). 


\subsection{Effect of $G$. japonicum Extract on SPT}

The repeated CORT injection significantly decreased the percentage of sucrose consumption as compared with the sham group. However, G. japonicum extract at a dose of $300 \mathrm{mg} / \mathrm{kg}$ significantly increased the percentage of sucrose consumption (respectively, $p<0.05$ ) (Figure 3).

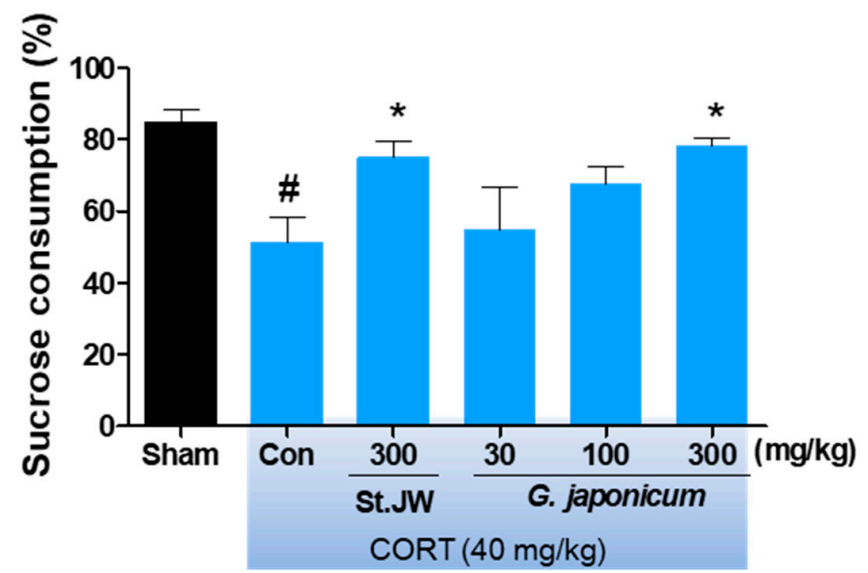

Figure 3. Effects of G. japonicum extract on sucrose consumption in CORT-induced depressive mice. CORT injections significantly decreased sucrose consumption, while treatment with $300 \mathrm{mg} / \mathrm{kg}$ G. japonicum extract significantly increased it. Results are presented as mean \pm SEM. \# $p<0.05$ versus the sham group; * $p<0.05$ versus the CORT-injected control group (Con).

\subsection{Effect of G. japonicum Extract on PAT}

As shown in Figure 4, the step-through latency of the CORT-induced depressive mice was significantly lower than that of the sham group; however, G. japonicum extract at a dose of $300 \mathrm{mg} / \mathrm{kg}$ significantly improved this deficit $(p<0.01)$.

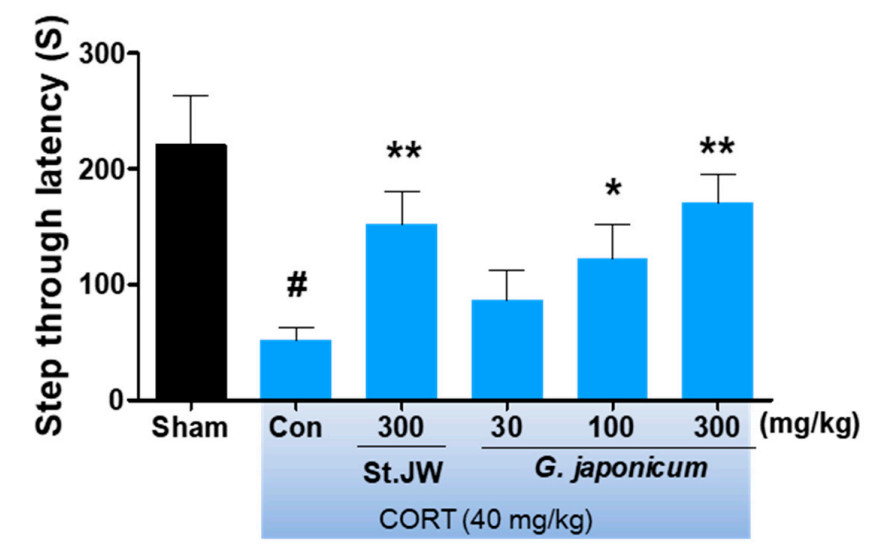

Figure 4. Effects of G. japonicum extract on the passive avoidance test in CORT-induced depressive mice. CORT injections significantly decreased step-through latency time (s), while treatment with 100 and $300 \mathrm{mg} / \mathrm{kg}$ G. japonicum extract significantly increased it. Results are presented as mean \pm SEM. $\# p<0.05$ versus the sham group; ${ }^{* *} p<0.01$ and ${ }^{*} p<0.05$ versus the CORT-injected control group (Con).

\subsection{Effect of G. japonicum Extract on TST and FST}

The repeated CORT injection significantly decreased the immobility times as compared with the sham group in the TST and FST. However, G. japonicum extract-treated groups had significantly reduced immobility times, with a maximum decrease in immobility of $32.1 \%$ at a dose of $300 \mathrm{mg} / \mathrm{kg}$ (Figure 5A,B). 

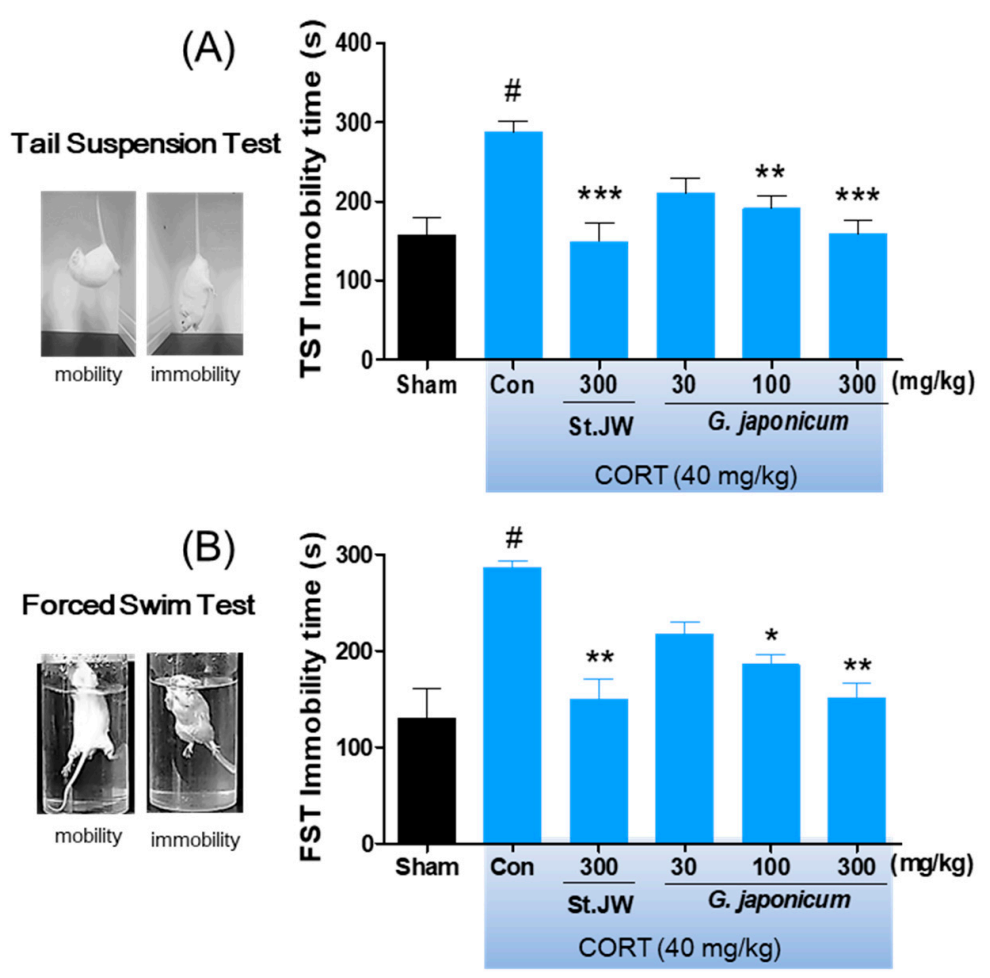

Figure 5. Effects of G. japonicum extract on the (A) tail suspension test (TST) and (B) forced swim test (FST) in CORT-induced depressive mice. CORT injections significantly increased the immobility time (s), while treatment with 100 and $300 \mathrm{mg} / \mathrm{kg}$ G. japonicum extract significantly decreased it. Results are presented as mean \pm SEM. \# $p<0.05$ versus the sham group; ${ }^{* * *} p<0.001,{ }^{* *} p<0.01$, and ${ }^{*} p<0.05$ versus the CORT-injected control group (Con).

\subsection{Effect of G. japonicum Extract on BDNF Expression in the Hippocampus}

After the FST behavior test, the mice hippocampus were isolated from whole brain for western blot analysis. As shown in Figure 6, repeated CORT (40 mg/kg, i.p.) injections for 28 days markedly reduced the BNDF protein expression levels in the hippocampus. However, G. japonicum extract $300 \mathrm{mg} / \mathrm{kg}$ and St. JW $300 \mathrm{mg} / \mathrm{kg}$ treated groups significantly prevented this deficit $(p<0.01)$.

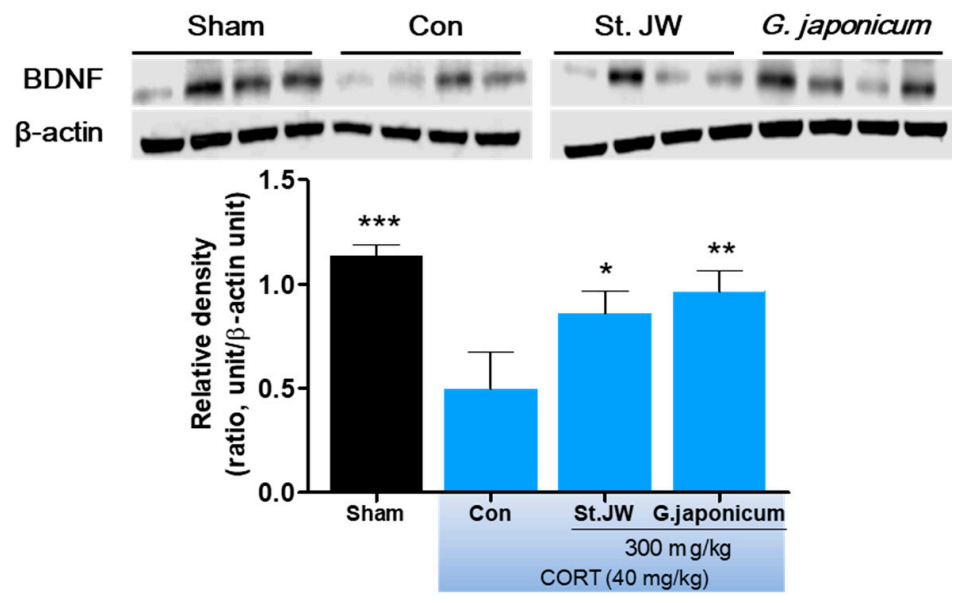

Figure 6. Effect of G. japonicum extract on hippocampal BDNF quantification by western blotting. CORT injections significantly decreased BDNF expression in the hippocampus, while treatment with $300 \mathrm{mg} / \mathrm{kg}$ G. japonicum extract significantly increased it. Results are presented as mean \pm SEM. ${ }^{* * *} p<0.001$, ** $p<0.01$, and * $p<0.05$ versus the CORT-injected control group (Con). BDNF, brain-derived neurotrophic factor 


\subsection{Effect of G. japonicum Extract on Neurotoxicity}

We determined the protective effects of $G$. japonicum extract on CORT-induced neurotoxicity in SH-SY5Y cells. We found that $200 \mu \mathrm{m}$ CORT significantly decreased cell viability by $50 \%$ compared with the controls $(p<0.001$; Figure 7A), which was prevented by co-treatment with $G$. japonicum extract $(p<0.001 ;$ Figure 7B).

(A)

(B)
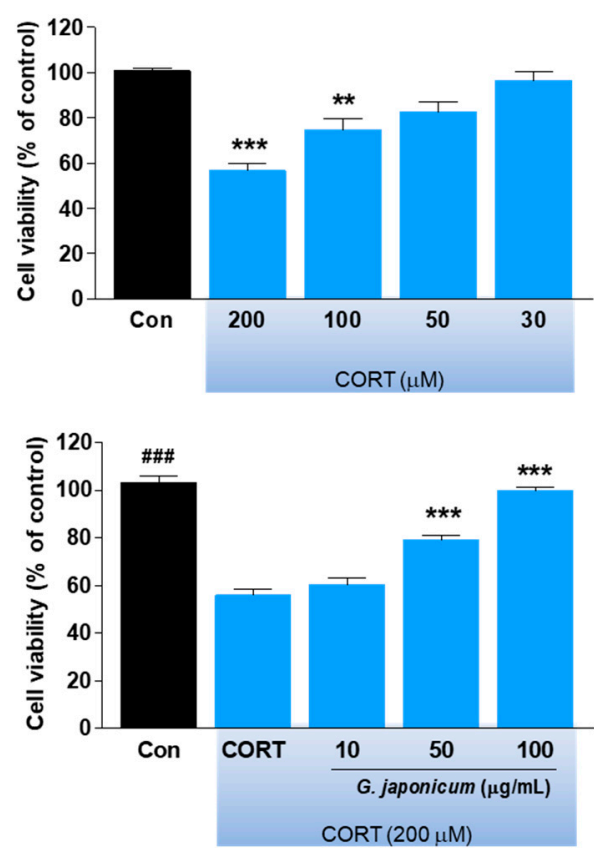

Figure 7. Effect of G. japonicum extract on CORT-induced cell viability in SH-SY5Y cells. (A) Dosedependent cell death induced by CORT in SH-SY5Y human neuroblastoma cells. (B) G. japonicum extract showed neuroprotective effects against CORT-induced toxicity in SH-SY5Y cells. Results are presented as mean \pm SEM. \#\#\# $p<0.001$ versus the normal group; ${ }^{* *} p<0.001$ and ${ }^{* *} p<0.01$ versus the CORT-treated control group.

\section{Discussion}

This is the first study on the antidepressant-like effects of G. japonicum extract on CORT-induced depression-like behaviors in mice, which is a well-established animal model for depression [19]. We found that $G$. japonicum extract prevented depressive-like behaviors, as shown by significantly decreased immobility times in the TST or FST and increased sucrose consumption without affecting locomotor activity. Moreover, G. japonicum extract improved cognitive function by prevention of reducing neurotrophic factor expression, which is involved in neuroplasticity. Additionally, G. japonicum extract showed protective effects against CORT-induced neurotoxicity in human neuroblastoma SH-SY5Y cells.

Although the complex pathogenesis of depression remains poorly understood, hypothalamicpituitary-adrenal (HPA) axis dysfunction is well-accepted as a risk factor for stress-related disorders, such as depression or anxiety [20]. The association between HPA-axis dysfunction and depression is suggested by the fact that many depressed patients exhibit cortisol hypersecretion [21] and impaired glucocorticoid negative feedback system [22]. In addition, exposure to high cortisol levels might be injurious to the brain, especially in the hippocampus or frontal cortex, which have a high concentration of glucocorticoid receptors [23]. Given that depressed patients have been reported to have a smaller hippocampal volume compared with healthy controls [24], the hippocampal volume predicts antidepressant efficacy in depressed patients [25]. Similarly, HPA-axis dysfunction in in vivo models is modified by chronic stress and controlled by treatment with antidepressants [26,27]. Further, 
glucocorticoid overexposure by repeated injection of high doses of CORT has been implicated in hippocampal apoptosis [28] and depressive-like behaviors [29]. The state of immobility in the TST or FST is reported to mimic the depression phenotypes in humans and can be ameliorated by treatment with antidepressant drugs [30]. Sucrose consumption in animals has been used as an indicator of anhedonia-like behavior. Anhedonia is a core symptom of major depression in humans [31]. We found that mice injected daily with $40 \mathrm{mg} / \mathrm{kg}$ CORT showed significantly increased immobility times in the TST and FST as well as decreased sucrose consumption. Further, we found that they had shorter step-down latency in the passive avoidance test compared with non-injected normal mice. This is consistent with previous findings on CORT-induced depressive or memory deficit behaviors in rodents [32,33]. As expected, we found that G. japonicum extract-treated groups showed significantly reduced immobility times in the TST and FST without any changes of locomotor activity, especially at the dose of $300 \mathrm{mg} / \mathrm{kg}$. Moreover, G. japonicum extract significantly increased the preference for sucrose consumption. These results suggest that G. japonicum extract has antidepressant-like effects in CORT-induced depression animal model.

BDNF, which is a member of the neurotrophins family, is highly expressed in the hippocampus and prefrontal cortex, and is involved in cognitive dysfunction and altered mood [34]. Numerous clinical studies have demonstrated that BDNF is an important factor in the pathogenesis of depression [35-37]. Further, serum BDNF levels are significantly increased by antidepressant treatment in depressed patients [38]. We found that the CORT-treated control group showed significantly decreased BDNF levels in the hippocampus. This is consistent with previously reported CORT-reduced BDNF expression in the hippocampus region [39]. As expected, we found that G. japonicum extract prevents the CORT-induced reduction in BDNF levels in the hippocampus. This suggests that G. japonicum extract potentially has antidepressant-like effects modulated by BDNF. However, the mechanism of the up-regulation of BDNF expression by G. japonicum extract remains unknown. Thus, further studies should confirm the antidepressant-like effects of $G$. japonicum extract using BDNF receptor, tropomyosin receptor kinase $\mathrm{B}$ (TrkB), and cyclic AMP response element-binding protein (CREB) signaling in the hippocampus or cerebral cortex.

CORT treatment has been reported to induce neuronal cell death by reducing BDNF expression in the hippocampus [40]. Further, glucocorticoid-induced cell injury has been used to screen potential antidepressants [41]. We used a model of neurotoxicity that mimics the glucocorticoid hypersecretion by exposing SH-SY5Y cells to CORT [17]. We found that SH-SY5Y cells co-treated with G. japonicum extract and CORT for $24 \mathrm{~h}$ showed reduced neurotoxicity in a concentration-dependent manner. This suggests that $G$. japonicum extract can protect against CORT-induced neurotoxicity.

A limitation of this study is that our in vivo findings present a portion of the animal's behaviors results, and dose does not reveal the bioavailability of the active compounds of G. japonicum extract. Thus, active compounds of G. japonicum extract need to be tested in vivo for their efficacy. Moreover, further studies are necessary to determine whether active compounds from G. japonicum extract act on the central nerve system by blood-brain barrier penetration. Taken together, our results indicate that G. japonicum extract ameliorates CORT-induced depressive-like behaviors in mice and that this activity might be mediated by up-regulating BDNF expression. Further, G. japonicum extract resulted in neuroprotective effects against CORT-induced neurotoxicity in human neuroblastoma cells.

\section{Conclusions}

To our knowledge, this is the first study on the antidepressant-like effects of G. japonicum extract on CORT-induced depressive-like behaviors in mice. We found that G. japonicum extract prevents against CORT-induced depressive-like behavior and that this effect may be mediated by BDNF regulation, which is involved in inhibition of neuronal loss. Our results suggest that G. japonicum extract may be useful in the treatment of depression. 
Author Contributions: J.L. and C.H.L. designed the study. D.W.L., M.Y.U., T.H., M.Y., J.L., T.-E.K., Y.T.K., and D.H. conducted the experiments and analyzed data. D.W.L. and C.H.L. contributed to the writing of the manuscript. All authors reviewed the manuscript and approved the final version.

Funding: This research was funded by Main Research Program of the Korea Food Research Institute, grant number E0164501-04.

Acknowledgments: This research was supported by Main Research Program of the Korea Food Research Institute.

Conflicts of Interest: The authors declare no conflict of interest.

\section{References}

1. Smith, K. Mental health: A world of depression. Nature 2014, 515, 180-181. [CrossRef]

2. Racagni, G.; Popoli, M. The pharmacological properties of antidepressants. Int. Clin. Psychopharmcol. 2010, 25, 117-131. [CrossRef] [PubMed]

3. Pirotta, M.; Willis, K.; Carter, M.; Forsdike, K.; Newton, D.; Gunn, J. 'Less like a drug than a drug': The use of St John's wort among people who self-identify as having depression and/or anxiety symptoms. Complement. Ther. Med. 2014, 22, 870-876. [CrossRef] [PubMed]

4. Liu, X.Q.; Yan, Y.; Li, F.; Zhang, D.F. Fruit and vegetable consumption and the risk of depression: A metaanalysis. Nutrition 2016, 32, 296-302. [CrossRef] [PubMed]

5. Wolniczak, I.; Caceres-DelAguila, J.A.; Maguina, J.L.; Bernabe-Ortiz, A. Fruits and vegetables consumption and depressive symptoms: A population-based study in Peru. PLoS ONE 2017, 12, e0186379. [CrossRef]

6. Liu, H.W.; Li, J.K.; Zhao, W.H.; Bao, L.; Song, X.H.; Xia, Y.; Wang, X.; Zhang, C.; Wang, X.Z.; Yao, X.S.; et al. Fatty acid synthase inhibitors from Geum japonicum Thunb. var. chinense. Chem. Biodivers. 2009, 6, 402-410. [CrossRef]

7. Dong, H.; Chen, S.X.; Kini, R.M.; Xu, H.X. Effects of tannins from Geum japonicum on the catalytic activity of thrombin and factor Xa of blood coagulation cascade. J. Nat. Prod. 1998, 61, 1356-1360. [CrossRef]

8. Kim, J.B.; Kim, J.B.; Cho, K.J.; Konig, G.M.; Wright, A.D. Antioxidant activity of 3,4,5-trihydroxybenzaldehyde isolated from Geum japonicum. J. Food Drug Anal. 2006, 14, 190-193.

9. Xu, H.X.; ming, D.S.; Dong, H.; But, P.P. A new anti-HIV triterpene from Geum japonicum. Chem. Pharm. Bull. 2000, 48, 1367-1369. [CrossRef]

10. Heo, J.C.; Son, M.; Woo, S.U.; Kweon, M.A.; Yoon, E.K.; Lee, H.K.; Choi, W.S.; Cho, K.J.; Lee, S.H. A fraction of methylene chloride from Geum japonicum Thunberg inhibits tumor metastatic and angiogenic potential. Oncol. Rep. 2008, 19, 1399-1403.

11. Xie, Y.W.; Xu, H.X.; Dong, H.; Fiscus, R.R.; But, P.P.H. Role of nitric oxide in the vasorelaxant and hypotensive effects of extracts and purified tannins from Geum japonicum. J. Ethnopharmacol. 2007, 109, 128-133. [CrossRef] [PubMed]

12. Ou, B.J.; Tao, W.; Yang, S.B.; Feng, J.T.; Wang, J.F.; Yang, T.; Wu, H.Y.; Huang, Y.G.; Tan, L.J.; Huang, W.F.; et al. The antiapoptosis effect of Geum japonicum Thunb. var. chinense extracts on cerebral ischemia reperfusion injury via PI3K/Akt pathway. Evid. Based Complement. Altern. Med. 2018, 2018, 7290170. [CrossRef] [PubMed]

13. Xia, S.F.; Shao, J.; Zhao, S.Y.; Qiu, Y.Y.; Teng, L.P.; Huang, W.; Wang, S.S.; Cheng, X.R.; Jiang, Y.Y. Niga-ichigoside F1 ameliorates high-fat diet-induced hepatic steatosis in male mice by Nrf2 activation. Food Funct. 2018, 9, 906-916. [CrossRef] [PubMed]

14. Chen, H.; Cheng, L.; Lin, X.L.; Zhou, X.P.; Cai, Z.M.; Li, M. Reconstitution of coronary vasculature by an active fraction of Geum japonicum in ischemic hearts. Sci. Rep. 2014, 4, 3962. [CrossRef]

15. Zhao, Y.; Ma, R.; Shen, J.; Su, H.; Xing, D.M.; Du, L.J. A mouse model of depression induced by repeated corticosterone injections. Eur. J. Pharmacol. 2008, 581, 113-120. [CrossRef]

16. Lim, D.W.; Han, T.; Jung, J.; Song, Y.; Um, M.Y.; Yoon, M.; Kim, Y.T.; Cho, S.; Kim, I.H.; Han, D.; et al. Chlorogenic acid from hawthorn berry (Crataegus pinnatifida Fruit) prevents stress hormone-induced depressive behavior, through monoamine oxidase B-reactive oxygen species signaling in hippocampal astrocytes of mice. Mol. Nutr. Food Res. 2018, 62, 1800029. [CrossRef]

17. Lim, D.W.; Um, M.Y.; Han, T.; Lee, J.; Kim, Y.T.; Cho, S.; Kim, I.H.; Han, D.; Lee, C. Standardized Citrus unshiu peel extract ameliorates dexamethasone-induced neurotoxicity and depressive-like behaviors in mice. Metab. Brain Dis. 2018, 33, 1877-1886. [CrossRef] 
18. Um, M.Y.; Lim, D.W.; Son, H.J.; Cho, S.; Lee, C. Phlorotannin-rich fraction from Ishige foliacea brown seaweed prevents the scopolamine-induced memory impairment via regulation of ERK-CREB-BDNF pathway. J. Funct. Foods 2018, 40, 110-116. [CrossRef]

19. Ali, S.H.; Madhana, R.M.; Athira, K.V.; Kasala, E.R.; Bodduluru, L.N.; Pitta, S.; Mahareddy, J.R.; Lahkar, M. Resveratrol ameliorates depressive-like behavior in repeated corticosterone-induced depression in mice. Steroids 2015, 101, 37-42. [CrossRef]

20. Mello, A.F.; Mello, M.F.; Carpenter, L.L.; Price, L.H. Update on stress and depression: The role of the hypothalamic-pituitary-adrenal (HPA) axis. Braz. J. Psychiatry 2003, 25, 231-238. [CrossRef]

21. Schule, C.; Baghai, T.C.; Eser, D.; Rupprecht, R. Hypothalamic-pituitary-adrenocortical system dysregulation and new treatment strategies in depression. Expert Rev. Neurother. 2009, 9, 1005-1019. [CrossRef] [PubMed]

22. Mason, B.L.; Pariante, C.M. The effects of antidepressants on the hypothalamic-pituitary-adrenal axis. Drug News Perspect. 2006, 19, 603-608. [CrossRef] [PubMed]

23. Nguyen, D.N.; Huyghens, L.; Zhang, H.B.; Schiettecatte, J.; Smitz, J.; Vincent, J.L. Cortisol is an associated-risk factor of brain dysfunction in patients with severe sepsis and septic shock. Biomed. Res. Int. 2014, 2014, 712742. [CrossRef] [PubMed]

24. Gonul, A.S.; Kitis, O.; Eker, M.C.; Eker, O.D.; Ozan, E.; Coburn, K. Association of the brain-derived neurotrophic factor Val66Met polymorphism with hippocampus volumes in drug-free depressed patients. World J. Biol. Psychiatry 2011, 12, 110-118. [CrossRef]

25. Colle, R.; Cury, C.; Chupin, M.; Deflesselle, E.; Hardy, P.; Nasser, G.; Falissard, B.; Ducreux, D.; Colliot, O.; Corruble, E. Hippocampal volume predicts antidepressant efficacy in depressed patients without incomplete hippocampal inversion. Neuroimage Clin. 2016, 12, 949-955. [CrossRef]

26. Raone, A.; Cassanelli, A.; Scheggi, S.; Rauggi, R.; Danielli, B.; de Montis, M.G. Hypothalamus-pituitary-adrenal modifications consequent to chronic stress exposure in an experimental model of depression in rats. Neuroscience 2007, 146, 1734-1742. [CrossRef]

27. Szymanska, M.; Budziszewska, B.; Basta-Kaim, A.; Jaworska-Feil, L.; Kubera, M.; Regulska, M.; Leskiewicz, M.; Lason, W. The effect of antidepressant drugs on the hypothalamic-pituitary-adrenal axis regulation in an animal model of depression. Bipolar Disord. 2008, 10, 88.

28. Lucassen, P.J.; Muller, M.B.; Holsboer, F.; Bauer, J.; Holtrop, A.; Wouda, J.; Hoogendijk, W.J.G.; de Kloet, E.R.; Swaab, D.F. Hippocampal apoptosis in major depression is a minor event and absent from subareas at risk for glucocorticoid overexposure. Am. J. Pathol. 2001, 158, 453-468. [CrossRef]

29. Iijima, M.; Ito, A.; Kurosu, S.; Chaki, S. Pharmacological characterization of repeated corticosterone injection-induced depression model in rats. Brain Res. 2010, 1359, 75-80. [CrossRef]

30. Renard, C.E.; Dailly, E.; David, D.J.P.; Hascoet, M.; Bourin, M. Monoamine metabolism changes following the mouse forced swimming test but not the tail suspension test. Fundam. Clin. Pharmacol. 2003, 17, 449-455. [CrossRef]

31. Liu, M.Y.; Yin, C.Y.; Zhu, L.J.; Zhu, X.H.; Xu, C.; Luo, C.X.; Chen, H.S.; Zhu, D.Y.; Zhou, Q.G. Sucrose preference test for measurement of stress-induced anhedonia in mice. Nat. Protoc. 2018, 13, 1686-1698. [CrossRef] [PubMed]

32. Lussier, A.L.; Lebedeva, K.; Fenton, E.Y.; Guskjolen, A.; Caruncho, H.J.; Kalynchuk, L.E. The progressive development of depression-like behavior in corticosterone-treated rats is paralleled by slowed granule cell maturation and decreased reelin expression in the adult dentate gyrus. Neuropharmacology 2013, 71, 174-183. [CrossRef] [PubMed]

33. Lee, B.; Sur, B.; Shim, I.; Lee, H.; Hahm, D.H. Baicalin improves chronic corticosterone-induced learning and memory deficits via the enhancement of impaired hippocampal brain-derived neurotrophic factor and cAMP response element-binding protein expression in the rat. J. Nat. Med. 2014, 68, 132-143. [CrossRef] [PubMed]

34. Duman, R.S. Neurotrophic factors and regulation of mood: Role of exercise, diet and metabolism. Neurobiol. Aging 2005, 26, S88-S93. [CrossRef]

35. Aicardi, G.; Argilli, E.; Cappello, S.; Santi, S.; Riccio, M.; Thoenen, H.; Canossa, M. Induction of long-term potentiation and depression is reflected by corresponding changes in secretion of endogenous brain-derived neurotrophic factor. Proc. Natl. Acad. Sci. USA 2004, 101, 15788-15792. [CrossRef] 
36. Matrisciano, F.; Bonaccorso, S.; Ricciardi, A.; Scaccianoce, S.; Panaccione, I.; Wang, L.; Ruberto, A.; Tatarelli, R.; Nicoletti, F.; Girardi, P.; et al. Changes in BDNF serum levels in patients with major depression disorder (MDD) after 6 months treatment with sertraline, escitalopram, or venlafaxine. J. Psychiatr. Res. 2008, 43, 247-254. [CrossRef]

37. Fernandes, B.S.; Gama, C.S.; Cereser, K.M.; Yatham, L.N.; Fries, G.R.; Colpo, G.; de Lucena, D.; Kunz, M.; Gomes, F.A.; Kapczinski, F. Brain-derived neurotrophic factor as a state-marker of mood episodes in bipolar disorders: A systematic review and meta-regression analysis. J. Psychiatr Res. 2011, 45, 995-1004. [CrossRef]

38. Sen, S.; Duman, R.S.; Sanacora, G. Meta-analysis of serum brain-derived neurotrophic factor (BDNF) levels in depression and antidepressant treatment. In Biological Psychiatry; Elsevier Science Inc.: New York, NY, USA, 2008; Volume 63, p. 98s.

39. Shen, J.D.; Ma, L.G.; Hu, C.Y.; Pei, Y.Y.; Jin, S.L.; Fang, X.Y.; Li, Y.C. Berberine up-regulates the BDNF expression in hippocampus and attenuates corticosterone-induced depressive-like behavior in mice. Neurosci. Lett. 2016, 614, 77-82. [CrossRef]

40. Nitta, A.; Ohmiya, M.; Sometani, A.; Itoh, M.; Nomoto, H.; Furukawa, Y.; Furukawa, S. Brain-derived neurotrophic factor prevents neuronal cell death induced by corticosterone. J. Neurosci. Res. 1999, 57, $227-235$. [CrossRef]

41. Zheng, M.Z.; Liu, C.M.; Pan, F.G.; Shi, D.F.; Zhang, Y.C. Antidepressant-like effect of hyperoside isolated from Apocynum venetum leaves: Possible cellular mechanisms. Phytomedicine 2012, 19, 145-149. [CrossRef]

(C) 2019 by the authors. Licensee MDPI, Basel, Switzerland. This article is an open access article distributed under the terms and conditions of the Creative Commons Attribution (CC BY) license (http://creativecommons.org/licenses/by/4.0/). 